\title{
The Era of Digital Transition in the Prism of the Existential Threat of Job Loss: Corporate Social Responsibility
}

Irina G. Shestakova ${ }^{1 *}$

1 Saint Petersburg Mining University, Saint Petersburg, Russian Federation; Irina_Shestakova@inbox.ru
* Correspondence: irina_shestakova@inbox.ru;

\begin{abstract}
This article explores the question of the rate of digital progress in the context of the labor market. Specific features of the current situation are indicated: temporality of socio-technological transformations, which is becoming less and less compatible with the harmonious development of man and society; the pace at which machines acquire intelligence; total devaluation of mental labor; unresolved issue of the role of man in the world of intelligent machines; the criticality of the problem of the labor market, due to its global nature, social significance and the rate of socio-technological changes. It is emphasized that these circumstances in the short term threaten the sustainable development of the global society, whose reactions to the transformation of technological and socio-economic infrastructure are significantly lagging behind. It is concluded that there is an urgent need to strengthen social responsibility, determined by the new ethics of relations between humans and machines with AI, supplemented by the primacy of the dignity of the social role of humans. The authors point out the urgent need to revise ideas about work as the main purpose of a person and about realization in the profession as the main factor that determines the self-esteem of an individual and his social status.
\end{abstract}

Keywords: digital transit; sustainable development; labor market; professional employment; economic sustainability; pace of development; artificial intelligence (AI); corporate social responsibility.

\section{Introduction}

At all levels of life of a modern person, from global politics to the daily routine of everyday life, over the past few decades, there have been cardinal changes. In this new reality, not only the emergence of a new information and communication field, which has radically transformed the usual infrastructure of social life, is critically important, but also the explosive growth in the rate of change caused by the breakthrough development of digital technologies.

The qualitative leap in the rate of development that has taken place determines the uniqueness of the residing historical moment. Fundamental change is happening in real time, creating both unprecedented opportunities and challenges that humanity has never faced in its history.

One of the most important life-forming spheres undergoing transformation during the rapid development of information and communications technology, which separates us far from the ontological space, in which mankind spent all its historical life within the framework of a predominantly traditional way of life, is the sphere of work. The reason of this is the rapidity of the onset of the digital economy that is determined by the internal temporality of digital technologies, which give a colossal increase in capitalization with a minimum consumption of resources and, due to this, radically transform the infrastructure of labor, totally displacing a person from the sphere of employment.

Contemporaneously, for the first time in the history of mankind, the pace of scientific and technological development comes into radical conflict with the harmonious development of man and society, and, therefore, calls into question sustainable develop- 
ment, especially in the aspect of the development of the world of work and the related sphere of education (its goals and objectives). This is especially important due to the fact that one of the markers that determine the balance of the economy and the life of society is the availability of jobs, which is defined in the goals and objectives of sustainable development [1].

\subsection{State of the Art}

The topic of the upcoming impact of digital technologies on the labor market is one of the most relevant in recent years, at the forefront, and it is considered from different points of view and with different conclusions.

At the turn of the XX-XXI centuries, a feeling arose that new information technologies would give potential advantages and significant prospects, becoming a "core" in supporting and expanding the employment sector, as evidenced, for example, by the Okinawa Charter on Global Information Society issued at the G8 Summit Meeting at Kyushu-Okinawa on 21 - 23 July, 2000 [2].

In the past few years, the problem of the impact of digitalization on the labor market has been actualized in interdisciplinary scientific research [3-5]. However, most authors, identifying complexity, arise with the advent of digitalization, nevertheless come to an optimistic scenario. For instance, into research Willem Pieter de Groen, Karolien Lenaerts, Romain Bosc and Felix Paquier, carried out for the European Economic and Social Committee at the intersection of social sciences, it is concluded that Digitalisation is expected to both destroy and create jobs, brining new opportunity in development of labor market [6]. Some specific questions in relation to its effects on the labor marke raise Degryse, Christophe, who are also coming to a possible optimistic scenario of the new possibilities opened up by the 4th industrial revolution [7].

While, the temporality of the development of technologies leads to the fact that after a few years it becomes clear that a person does not keep up with the super-fast development of information technologies [8] that is why a person is offered to study and learns a lot. This makes Lifelong Learning emerging as a pivotal agenda item in the World Bank Group's 2019 World Development Report [9]. In 2017, the World Economic Forum publishes the report about accelerating retraining for the Fourth Industrial Revolution, which highlights that more than a quarter of workers have a mismatch between their current skills and the required qualifications for their work [10]. UNESCO is creating a global network of lifelong learning cities, the so-called Learning Cities [11], trying to find the right mix of resources, institutional structures, modern technology and cosmopolitan values to serve as incubators and drivers for 21st century knowledge societies [12-14]. Access to high-quality education for all mankind has the basis for the purposes and objectives of sustainable development [1].

At the same time, those at the forefront of developing the technologies themselves are not so optimistic. Their least painful warning is that all the professions for which we prepare students today will be gone by the time they graduate. Leaders of scientific research such as Elon Musk, Bill Gates, and Jack Ma are making the even more alarmist assumption that artificial intelligence is likely to completely displace humans from the world of work [15-17].

Nevertheless, in these conditions, enormous efforts of states [18-19], corporations, research teams [20] and individual scientists [21-26] are aimed at developing the problem of AI ethics. Whereas unanswered remain questions the existence of a person in a world where his professional skills are not in demand, where the goal through which he builds his professional and, therefore, social existence, at once loses its relevance; as well as the question of the ethics of social responsibility for the ongoing socioeconomic transformations and the place of a person in a new paradigm, where it is difficult for him to find himself and build his life path (and, consequently, the meaning of life), since everything 
that he is aimed at suddenly turns out to be "removed" from his area of responsibility, vocation, management and duties.

Thus, in this paper, we want to consider the issue of the pace of digital progress in the context of the labor market, with an understanding of the role of regulation and social responsibility in the radical transformation of this area, occurring at superhuman speed in connection with the sudden emergence of intelligent machines.

\subsection{Historical retrospective}

In the intellectual world, the very first steps of the industrial revolution caused heated discussions about the place and role of man in this industrial world, about how the appearance of such machines, factories, and steamships affects them [27-28]. Over time, physical labor was largely supplanted by mechanical machines, and by the second half of the twentieth century human employment was redistributed into the service sector or "tertiary sector", as it is classified by J.-M. Ferry, covering all public and private services, from beauty salons to public education and healthcare, including commerce and public transportation [29].

The third industrial revolution and the emergence of computing technology set a new vector for this problem. There is a tendency to redistribute jobs in the direction of jobs related to the information sphere. Actually, the beginning of the information society - its "project" period, is considered to be a statistical report that appeared at the end of the 50s last century in the US Department of Commerce, showing that for the first time in history the number of employees exceeded the number of production workers.

The appearance of computers in the middle of the twentieth century raises a discussion about the special role of intelligent machines, their possible rivalry with people, the problems of the future caused by this direction of technology development (N. Wiener [30], J. C. R. Licklider [31]).

In the second half of the twentieth century, there is a surge of interest in understanding the observed transformation of society in connection with the progress of infocommunications (in particular, printing, television and the first computers). A detailed analysis of these phenomena is contained in the works of J. Fourastier, N. Wiener, D. Bell, M. Heidegger, M. Castells, K. Jaspers, E. Toffler, M. McLuhan, N. Luhmann, J. Habermas and others [32-36]. At the same time, skepticism appears in relation to the "cybernetic revolution", which, according to D. Bell, turned out to be "illusory" [37].

Later, E. Toffler, D. Bell, and D. Naisbitt were also engaged in it [37-39]. Naisbitt, for example, writes that in 1950 only $17 \%$ of Americans worked in information-related jobs. Now $65 \%$ of all employees work with information - programmers, teachers, clerks, secretaries, accountants, stock brokers, insurance agents, officials, lawyers, bankers and engineers. And many more workers in manufacturing companies are also busy working with information. Most Americans devote their time to creating, processing, and disseminating information. For example, employees of banks, stock market and insurance are all busy with information [39].

As we can see, until recently, the problem of jobs was brewing and, historically, over time, it was somehow solved. However, the formation of a digital civilization brought its own unique specifics to this issue. Let us analyze them.

\subsection{Distinguishing features of the current situation}

1.3.1. Pace. The disappearance of professional strata before the eyes of one generation.

In the history of technological development, we certainly find examples of the disappearance of professional strata. A fairly striking famous example is the Luddite uprising. But such stories dealt with individual professional strata in fairly local fields. In world space at that time, such changes occurred much more slowly. Any one change could occur over the life of many generations, thus they were practically invisible. 
That is, progress and the transformations of professional spheres caused by it took place at all times; however, the development of civilization went so slowly that during the life of one generation the changes were almost invisible. The speed of change was incomparable with the speed of the processes that started from the moment of industrialization, when the picture of professional activity began to change rapidly.

The resulting qualitative leap in the rate of development leads to the fact that the fundamental transformations of the technological and the revolutionary changes in the social and economic environment caused by them, which have an instantaneous effect on all mankind as a whole, for the first time in the history of mankind began to happen many times during one human life [40].

The specific temporality of the development of the digital world leads to the fact that the transformation of the world of work with the radical reduction of huge professional niches begins to occur non-stop before the eyes of one generation. At the same time, such a development of events, even at the beginning of the XXI century, seemed absolutely incredible. Thus, in 2001, Michael Porter, in his at that time discussion article "Strategy and the Internet" [41], recorded new trends in the relationship between the seller and the buyer. The article provoked rejection, as it indicated that the need for regular sellers was disappearing, replaced by the relationship between the seller and the buyer in the Internet space. It was really difficult to believe in it. Porter later develops this theme in terms of competition in a new market, built using the capabilities of the World Wide Web. In his opinion, new technologies enhance the process of evolution of the seller-buyer relationship, leading to significant changes in many areas [42]. However, such a combination of circumstances was predicted by N. Wiener, who pointed out that "an automatic machine ... is the exact economic equivalent of slave labor. Any labor force that competes with the slave labor force must accept the economic conditions of slave labor. It is quite clear that this will create a situation of unemployment, compared to which the present recession and even depression of the thirties will seem like a pleasant joke" [30].

If at the beginning of the XXI c. such statements caused controversy, but today it is an obvious problem that is at the peak of its relevance. Discussions are being conducted in a variety of areas. We hear them from the mass media, from discussions in expert communities. The impact of digital transformation on jobs is at the forefront of scientific reflection and policy debate around the world [43-45].

In 2012, CNN tried to figure out which professions would become obsolete and which would reappear[46]. Later, in 2016, the list of popular professions by 2025 is published by Microsoft [47]. The problem of the loss of professions was devoted to the World Economic Forum in Davos in 2016 [18]. It became obvious that we are facing the risk of losing mass professions, such as professions in trade, transport, etc. Many foreign researchers come to the conclusion that in as a result of technological progress in industrialized countries, a large number of skilled and unskilled labors will be freed from the production process. The real picture indicates that during the life of one generation professions disappear; entire professional strata are washed out of the economy or undergo radical changes.

The remaining share of labor is melting before our eyes. With each passing moment, there are fewer and fewer things that humans do better than computers. The downsizing associated with ICT development does not only affect areas of simple, routine work that can easily be replaced by software. This is not liberation from routine labor, but complete liberation from labor. After all, modern machines are not just machines; they are the bearers of artificial intelligence [48]. They are already capable of not only routine work. They play chess, write poetry, and perform operations. A possible reduction can be seen in professional niches that require the highest intellectual abilities, education, intuition, for example, in the field of scientific research.

The developments taking place in the labor market are not just a consequence of the washing out of professions. The problem lies in the reduction of the total volume of labor in individual segments of the economy. As we have shown above, these are drivers, security guards, workers of factories, banks, etc. This is a forward movement that takes 
place throughout the history of mankind, but in the temporality of the digital age, the total volume of labor is reduced almost simultaneously and at the global level.

1.3.2. Development of AI. Machine - Automatic - AI - Super-AI. The machine has ceased to be just an assistant, performing only the functions of a physical machine. She acquired intelligence, with a penchant for superintelligence.

Up until now, such an idea existed as a myth, embodied, for example, in the image of an animated clay giant Golem, which, according to the creators' idea, had to satisfy human needs, because since ancient times people have dreamed of an assistant who knows how to work hard. However, the Golem, gradually gaining experience, began to declare its will, becoming dangerous for the person himself [49].

We find a philosophical perceptive of this problem in the work of the American scientist Joseph Licklider "Man-Computer Symbiosis In: Transactions on Human Factors in Electronics" [31], in which he argues that the function of a machine cannot be a guide a computer must forever become a human assistant. In this sense, the machine is seen as a weak-willed helper carrying out the will of man.

Until recently, this idea was supported by the complete conviction that the human mind, of course, surpasses the capabilities of both the animal and the artificial world, since the machine does everything only by listing the programmed programs, and the person acts incomprehensibly correctly, since the spark of God is enclosed. Hence, this meant the endless field of application of the human mind.

The seed of doubt was sown at the moment when the grandmaster, as a representative of the intellectual elite of humanity, lost to a computer in chess. Thus, in effect, every moment fewer and fewer people are performing better than computers. The remaining share of labor is melting before our eyes. The downsizing associated with ICT development affects more than just areas of simple procedures that can be easily replaced with software. This is not liberation from routine labor, but complete liberation from labor. After all, modern machines are not just machines; they are carriers of artificial intelligence. They are already capable of more than just routine work. They play chess, write poetry, and perform operations. A possible reduction is observed in professional niches that require higher intellectual abilities, education, intuition, for example, in the field of scientific research.

1.3..3. In the current situation, the issue of reducing the labor market is becoming socially significant not only for some particular part of the population, but also relevant at the mass level, since at the moment in question almost all of humanity is involved in labor activities.

This was facilitated, firstly, by the absence of a global war in which a huge part of the male population could realize themselves. Consequently, all men who previously served in the army are involved in work, they take jobs. Secondly, the 20th century, especially its second half, was marked by gender equality and the emancipation of women, who by now are involved in a significant number in the labor process.

Thus, in the conditions of a digital civilization, when the technological infrastructure undergoes radical changes almost simultaneously, covering all continents, transformations in the world of work affect not one stratum in one local place, but all of humanity, since practically all. In this regard, if today almost $100 \%$ inclusiveness is still being held back, then tomorrow, given the current development of the situation, it may turn out to be exclusivity close to the same $100 \%$.

\subsubsection{Robots take the kind of work that is pleasant to humans.}

Hard physical labor has significantly decreased by today (with the exception of some professional niches: janitors, builders, farmers, who still work, albeit with the help of technology); even skilled labor is minimized. The conveyor belt has also been supplanted, but routine intellectual work still remains and occupies a huge part in the total 
volume of labor. This is a niche of so-called "white collars", which has partially taken over former workers. We find an understanding of this fact in the works of E. Toffler, M. Castells, D. Bell, and others [37,50]. But even this clean and relatively pleasant work is already being adopted by machines.

The modern machine even invades the segment of highly advanced routine work. This, paradoxically, may be people of the highest qualifications, highly intellectual, solving specific problems (including scientific ones, for example, in natural science: in physics, chemistry, and biology). This is a huge part of humanity, which, with all due respect and respect for them, has neither the ability nor the inclination to creative activity. Such people will be left without work. At the same time, people who are able to do non-standard work are a minority.

At the same time, people love such work, they are proud of their position. In the modern civilized world, there are already many people who are rich from birth, own estates and have decent savings. With such freedom and, of course, education, they crave work, seek a job, even without pay, and tremendously appreciate the opportunity to come to work, do something, solve problems, because not only "monetary rivalry" [51] motivates a person. They go to work at the university, treasure this place, having great ambitions. At the same time, the level of their well-being may be several orders of magnitude higher than that of any employee, but they are dependent - they humanly want recognition, self-realization, and they see this in their realization in a profession that depends on them, and not on their money. For such people, work is associated with life this is such an ambiguous life with multidirectional emotions: rise, failure, ups and downs, nervous breakdowns and joys, but he does not want the quiet life that is provided for him. This attitude to work is typical. In addition, and this is probably the determining factor: a profession is identification, position and respect in society. In The Arizona Dream, the protagonist talked about his father, who worked as a petty police officer and appreciated his job very much. The father instructed his son that work is like a hat. When it is on your head - you feel good, and when there is no hat - you feel like an absolute blockhead. Likewise without a job. If there is a job - the person is respected (there is some kind of social status), if not - you do not know who you are [52].

Reconsideration of the problem of relations in the man-machine system at the present stage of scientific and technological progress shows that the already achieved degree of development of digital technologies inverts the question of the place of technology in human life into the problem of determining the role of man in the modern world of intelligent machines. Historically, one of the most important achievements of scientific and technological progress was the deliverance of mankind from hard, harmful physical labor. The arrival of intelligent machines is able to free a person even from the (so desired) mental labor, in which a modern person finds not only satisfaction of the natural need to work, but self-realization, socialization, structuring of life, and in many cases the meaning of life itself.

The basis for this conclusion is the progressive depreciation and displacement of mental labor in a digital society, as well as the expectation of a sharp increase in this trend with the development of artificial intelligence. The work of robots can ensure the material well-being of society, but in the context of the temporality of the digital world, the prospect of a sharp decrease in the need for human labor leads to the need to revise generally accepted ideas, especially ideas about the future, which determine the construction of the life trajectory of any responsible person or corporation.

\section{Materials and Methods}

The work will be based on socio-philosophical principles and methods of cognition. The interdisciplinary status of the problematic field of research will require the applica- 
tion of a synthesis of methods for a comprehensive analysis of the current situation and the construction of alternative scenarios for the future in the context of narrowing the horizons of foresight caused by the ultra-rapid progress of technologies.

The application of the method of participatory observation and the use of well-known experimental and statistical data with the analysis of the results obtained will make it possible to rethink a number of phenomena and trends that appear in the current situation of the "life world" of a person and society in the conditions of a radical acceleration of scientific and technological progress and a sharp increase in the transformation of socio-economic infrastructure.

\section{Results}

Here an open question is alarming: in history, the deliverance of mankind from heavy, harmful physical labor was viewed as a generous mission of scientific and technological progress. However, almost before our eyes, the developing intelligent machine suddenly encroached on all working niches. Equipped with artificial and now super-artificial intelligence, it is more efficient than people in almost everything. The segment where the person surpasses the machine decreases at every moment of time. If before the machine, placing "on its shoulders" heavy, hated physical labor, freeing a person from the need to use the animal essence in the labor process, today it takes away from a person easy, pleasant and desired work, in which a person finds motivation, socialization, realization, structuring life and pleasure in general. Thus, a person is deprived of the understandable opportunity to manifest his human essence.

A similar situation poses challenges to the existing paradigm of the usual basic ideas about how to live in this world. An optimistic humanity will give the answer - enjoy. Perhaps life will be very positive in terms of material well-being and physical condition of people. But what should a person do in this situation? For man, only to enjoy is to live an animal life. On the one hand, this does not contradict human nature and it corresponds to the way of life in paradise, as described in the Bible, on the other hand, human nature requires competition, work. Perhaps that is why people do not want to live in paradise.

Keynes J.M. writes that it is generally accepted that in a society of abundance, everyone will dance and sing psalms [53]. This is how a society of people freed from the need to work was presented. We find a similar picture of a carefree life, where people sing and dance, in H. Wells' novel The Time Machine. However, Keynes, in his work comes to the conclusion that "a person needs work"[53].

The famous psychologist Viktor Frankl, the founder of the method of existential psychoanalysis - logotherapy, comes to a similar conclusion in his practice. His professional experience shows that in the absence of work, a person feels emptiness, lack of meaning in life [54]. Frankl himself believed that "a person completely wrongly identifies his professional vocation with the life task for which he was called into this world [54]. Nevertheless, professional experience convinces Frankl that a person's life "is filled with meaning through work", and unemployment becomes a "nutritious environment for the spread of neuroses" [54].

Considering the potential for labor in the middle of the 20th century, N. Wiener, who stood at the origins of the computer era, points out that "an automatic machine ... is the exact economic equivalent of slave labor. Any labor force that competes with the slave labor force must provide the economic conditions for slave labor. It is clear that this will create a situation of unemployment, compared to which there is a recession and even depression of the thirties will seem like a pleasant joke" [30]. He doubts that "it would be good for humanity if machines got rid of the need to do dirty and unpleasant work" [30]. What can we say if a modern machine relieves him of pure, noble and pleasant labor?

It should be noted that the socioeconomic paradigm took shape in the historical development of mankind. The industrial era has left a special imprint, finally forming, 
which has become traditional today, the idea of the purpose of a person (in the narrow sense, as understood by the majority of the population), which consists in the need to work, grow professionally and, as a result, acquire social status through a profession. The understanding of labor as its purpose, self-realization, and, consequently, as the purpose and meaning of life is cultivated by all social institutions.

In the context of everything that happens, when we are not able to predict the future, the question naturally arises about the purpose of a person, which is especially relevant for a person of Western culture who seeks to take place in this world. His status is associated with how he made himself, how he took place in work, in his career. This understanding created a pivot - a person, by default, knows his purpose (in a general sense), and knowing it, he feels more comfortable walking the beaten path towards a clear goal.

The understanding of the need to work throughout life is cultivated by education. All stages of life: childhood, school, college - all these are stages to work. From childhood, a person tunes in and prepares for the fact that he will work there, in work: in a career, in a salary, in status - he will show himself, show himself. This is what his parents expect from him. In accordance with this task, the goal of life is largely built. At the same time, there are various evidences of this realization: interest, aspiration, conscious choice. This has long been important for men, and in many ways it has become important for women.

There are other ways to achieve public recognition, less common: social activities, helping those in need. But they are meaningful only against the background of work. Work for many is a measure of self-identification, a sign of belonging to something greater, an opportunity to proudly declare their social status. Since in the near future only a few high-class, "special" people who cannot be replaced by a robot or any program will work, self-identification, apparently, will proceed simply according to the principle: you work or you don't.

Thus, the potential for one-step washing out of the world of work from the ontological field of human existence can lead to revolutionary transformations with all the consequences in relation to the feeling of loss of the usual style and way of life. As a result, such new trends are engendered as a decrease in motivation for education and self-improvement, up to a complete change in lifestyle and behavioral stereotypes. This causes a well-founded anxiety generated by the uncertainty of a rapidly advancing future with an unresolved question about the place of a person as a working professional in the world of intelligent machines.

The civilization scale of these transformations and trends becomes clear in the context of the key role that human involvement in professional employment has played in the history of mankind.

The consequence of such a speed of destruction of meanings is that a new meaning must be developed energetically - in the temporality of the digital world, which contradicts the nature of man (our inner temporality).

The indicated situation of transformation of the world of work, when almost all of humanity is involved in it, with an undefined role of man in the world of intelligent machines, occurring in the specific temporality of the digital world, can be designated as an existential threat to a social organism, whose reactions to changes in the technological environment are significantly lagging behind. Accordingly, there is a need for a socio-philosophical reflection of these processes.

\subsection{The urgent need for a new ethics of social responsibility}

In the past decade, the world has sounded the alarm about the rapid development of AI. More and more states are investing (money and effort) in an attempt to be the first in this race for super-strong AI. At the same time, scientists are alarming about the consequences that can arise in the human community under these conditions. Research centers are opening up everywhere focusing on the ethics of AI [20,55-57]. 
The question of machine ethics is undoubtedly important and a huge number of the best minds are engaged in it [21-23, 58], but we believe that the question of the existence of a person (social personality) is no less important, especially in connection with its existential nature. In a world where "the use of artificial intelligence and robotics systems as more functional than traditional systems can potentially improve the quality of life for consumers [95]. "

The pace with which the digitalization of jobs is taking place, as a result of the contraction of the labor market with the devaluation of the role of a person in the labor process, requires the government to take responsibility in some areas in relation to the person "working". In the temporality of technological development of previous eras, the job problem was solved by the method of reactive response. The speed of modern socio-technological transformations requires proactive actions, for which we are completely unprepared.

Thus, the problem is ripe; it corresponds to a new moment in the life of mankind, and as a result should be on the agenda, at the forefront of research in social philosophy. That is why we believe it is necessary to assert the ethics of social responsibility, which regulates the relationship of a person with intelligent machines and, under all conditions, determines the primacy of the dignity of a person's social role.

3.2. Let us outline some of the areas of social responsibility that we consider important in the digital transit era.

3.2.1. Recognition of the fact that it is impossible to spontaneously harmonize the labor market.

Despite the challenges of our time, mankind for the most part continues to be in a sense of inertial stability, that the spontaneous harmonization of the labor market, which has always happened, will also occur in the digital civilization.

An inertial sense of stability in the labor market is rooted in a variety of sources. Firstly, from the soil of history (and from the linear continuation of the historical course), and secondly, from various momentary interests, it is proclaimed in every possible way by the state heralds.

Continuation of the historical trend. Indeed, based on the historical realities of the relationship between man and machine, we see that the problem of jobs has always been solved in some way.

In the fact of development on a historical scale of time, similar cases of occupation of jobs by technologies looked like episodes that were always overcome - the loss of some job niches was compensated by the emergence of new ones [60]. At the same time, the introduction of new technologies into production led to the fact that labor productivity increased, the labor market was transformed, new segments and niches arose, as a result of which there was a demand for an increasing number of workers.

The future is unpredictable, especially unpredictable in the temporary conditions of the formation of a digital civilization. However, if we remain within the framework of a historically and empirically manifested trend, it is reasonable to assume that in some natural way everything is harmonized. The facts of history create the feeling that, despite the arrival of a new reality, humanity will automatically work out some kind of solution, therefore, in this digital world, a person will still find a niche for applying his profession and will be busy in the labor process and possibly even working hands that should not be overlooked.

This feeling is invariably supported by the politics of many states. We are talking about raising the retirement age, inviting migrants, as well as persistent advertising of gig workers [61-63] with high skills - with skills that employers need here and now [64], not a universal education.

A similar personnel policy is pursued under the rule of technocrats. Indeed, in a spontaneous market economy, when everything is released to the market, to competition, as a result, everything is aimed at technical progress - it is advisable that what is profita- 
ble here and now - at the current short moment. Although in the long term, as a rule, the involvement and use of new technologies in the labor process actually led to overall success and prosperity.

However, today this variant of spontaneous development is unacceptable, since it leads to absurdity.

Indeed, most likely, given the fact that robots (automatons, including those with AI and super-AI) are more efficient than humans, in the context of such a policy, the value of human labor will inevitably depreciate in the near future, with a reasonable replacement of it not a smart car. This means that the unrestrained formation of a digital civilization and, as a consequence, the development of intelligent machines will lead to their total use in all professional niches, devaluing the social status of a person, and this is absurd.

Thus, despite the historical experience of spontaneous harmonization of human relations with technologies, we come to the absurdity of a purely technocratic development scenario, when intelligent machines oust a person in the labor market. Therefore, it is necessary to recognize the fact that spontaneous harmonization of the labor market is unlikely, given the pace of technology development and socio-economic transformations, which corresponds to the formation of a digital civilization. In this situation, the life-saving scenario can be at least partially "humanistic", achievable through controlled harmonization of the labor market. Regulatory policy takes time.

\subsubsection{Providing a person with work during the transition period.}

There can hardly be any doubt that humanity is able to find adequate answers. However, the problem here is that under the conditions of the emerging digital reality, revolutionary changes are taking place, one of the main features of which is its inherent specific pace, when fundamental socio-technical transformations occur repeatedly during one human life; which does not allow postponing the decision for some distant future.

Klaus Schwab (Executive Chairman of the WEF) at the World Economic Forum 2020 noted that the emergence of the Internet in our lives is the reason for the creation of a "culture of emergency response"[65], but we assume that today the most important (one might even say - significant) need to solve the problem of "erosion" meaning of life. Moreover, this is important not only for future generations, about which Schwab speaks, but already for the generation that lives today. The speed with which the situation is evolving suggests that the problem will affect almost all of us. That is why the use of the so-called "dictatorship of urgency" is urgently required.

Thus, taking into account the importance of professional employment in the life of a modern person, as well as the difficulty of accepting new conditions in which he will not work, and the time lag required for this, we believe that the regulation of this process will be humane.

In this sense, one of the tasks of the new ethics of social responsibility is to ensure employment and professional relevance of a person. This approach is important, at least during the transition period in which all of humanity is located, as part of a digital civilization.

Potentially, this can be an artificial (legislative) decision to attract human labor, as well as various compensation mechanisms, which Vivarelli considers, for example, in his works [66]. And, as we can see, there is movement in this direction.

3.2.3. Preparing a person for a sharp paradigm shift and for facing an existential problem. Creation of the paradigm of the "non-working" person.

The creation of jobs or the application of different methods of regulation is an extremely important step, but it is necessary during the transition period. At the same time, one of the main tasks of the new ethics of social responsibility in the context of the temporality of socio-technical transformations in the digital age is to understand and accept the situation. Recognition of the fact that in an era of such rapid development of intelli- 
gent machines, the likelihood of unemployment is extremely high. At least, this applies to employment in the modern sense, when work is provided by the employer in compliance with the prescribed requirements that shape the working day and, as a result, the life of a person.

As a consequence, this understanding must be conveyed to the consciousness of each person. We want to say that humanity must be ready for this and thus, to get rid of the illusion of the demand for their work. A person must understand this and prepare for another future, perhaps a better one. Moreover, it must happen at a pace that matches the pace of digital development. Then they will begin to build their life in a different way today. And this is the new role of the social thinker.

\subsubsection{Development of new meanings}

Thus, the sudden intrusion of digital civilization into our life with the rapid devaluation of mental labor raised the question of the urgent need to revise the concept of labor as the main goal of a person and implementation in the profession as a basis for building a life trajectory. We therefore come to the need to revise the very foundations of understanding the meaning of human life, his motivation, including answers to questions about what it means to have a place in this life, and not in vain to live it. This will express concern for the person himself, and this is necessary first of all for each individual person. In all likelihood, the new reality requires a new person with a different average archetype, with a different set of basic attitudes, possibly with a different psycho type: more open and tolerant of changes. Such a statement is not new, but the understanding of this fact in modern conditions has a special depth, since for a person "habit is second nature." His whole being is in the world of attachments, traditions, relies on the sensual, emotional sphere, which is based on basic attitudes. In the new reality, it is not only the new meanings and purpose of a person that are significant; their very attitude to reality requires revision. For a new picture of being, you need a person with a new vision of the world and yourself in it.

It should be noted here that the situation has arisen and is developing in the temporary conditions of a digital civilization. At this pace, characteristic of digital development, it is necessary to consider the issue of a possible revision of ideas about the implementation in the profession as a basic value that determines both a person's self-esteem and his status in society.

The ethical aspect of this problem lies in the social responsibility of the state for what is happening and the consequences. The pace of digitalization requires a vigorous rethinking of existing concepts and ideas. However, the dialectical contradiction lies in the fact that the speed of socio-technological changes of the era after a qualitative leap in the rate of development leads to a sharp narrowing of the horizons of scientific foresight, critically increasing the risk and cost of mistakes when choosing decisions regarding plans for any development, including infrastructure, economic and military-industrial. Particularly acute is the problem of the formation of the personality itself, which includes not only the requirement to modernize the concepts of upbringing and education, but also the revision of fundamental ideas about human purpose and basic values, since their core idea of a person self-realization in the profession is already at the next stage in the development of digital technologies and artificial intelligence may be untenable.

The social responsibility of the state, including the urgent task of a social philosopher, is seen in an attempt to rethink the existing ideas about the purpose of a person in relation to the new digital era. And further, if we speak in the most general sense, try to build an ideal image of a person corresponding to this new destiny, that is, a model of a person that is adequate to the new reality of the digital world. At the same time, a new picture of being with all its details, as well as all concepts of the formation of a person, adequate to the new reality, should be presented taking into account the extremely limited unpredictability of even the near future.

This is necessary because the extremely blurred picture of the technological future at this rate is only one problem. More essential here are questions that lie in the humani- 
tarian plane: about the purpose of a person, about what is good ("happiness"), about the responsibility of society for the results of socio-technological development, that is, the eternal questions that have made a transit into a digital civilization and require their understanding of the energy that corresponds to the temporality of the digital world. The future itself depends on whether the answers will follow in time (that is, immediately) and what they will be, which, in the spirit of Wiener's philosophy, should not be determined only by the spontaneous play of techno-economic forces (mechanistic principles such as "least action" or the least free energy), but also by the principles, developed over millennia, of humanism and ideas about the aspirations of the human spirit.

\section{Discussion}

Thus, having considered the issue of the rate of digital progress in the context of sustainable development goals in general and the development of the labor market, in particular, we came to the conclusion that there is a categorical need for regulation in this area, especially in conditions when the rate of socio-technological transformations may exceed the adaptive capabilities of a person and society.

It is noted that suddenly emerging conditions, when transformations of the world of work with an indefinite role of a person occur in a certain temporality of the digital world, can be designated as an existential threat to a social organism, whose reactions to changes in the technological environment lag significantly behind.

We believe that, despite the historical experience of spontaneous harmonization sustainability of human relations with technology, there should be a new ethic of social responsibility that regulates human relations with intelligent machines and, under any conditions, determines the primacy of the social role of a person.

Along with this, the inevitable reduction of the knowledge-based labor market exacerbates the problems and target of sustainable development. The marked fact requires a revision of the understanding of labor as the main purpose of a person, which has developed over the past several hundred years and is cultivated by all social institutions, and, accordingly, the idea of implementation in the profession as a basic value that determines self-esteem and status in society. This need calls for the responsibility of the philosophical and sociological communities and requires from them full involvement and enormous effort.

Author Contributions: Conceptualization, I.S.; methodology, I.S., formal analysis, I.S.; investigation, I.S.; writing-original draft preparation, I.S.; writing-review and editing, I.S.; funding acquisition, I.S. The author has read and agreed to the published version of the manuscript.

Funding: This research received no external funding

Conflicts of Interest: The author declare no conflict of interest

\section{References}

1. United Nations (2017) Resolution adopted by the General Assembly on 6 July 2017, Work of the Statistical Commission pertaining to the 2030 Agenda for Sustainable Development (A/RES/71/3133).

2. The Okinawa Charter on the Global Information Society. 2000. URL: https://www.itu.int/net/wsis/links/listing.asp

3. Report of the HLEG on the Impact of the Digital Transformation on EU Labour Markets. (2019). European Union, 2019. URL: https://ec.europa.eu/digital-single-market/en/high-level-expert-group-impact-digital-transformation-eu-labour-markets;

4. Bowles J. (2014) The computerisation of European jobs. http://bruegel.org/2014/07/ the-computerisation-of-european-jobs/;

5. industriAll (2015) Digitalisation for equality, participation and cooperation in industry - More and better industrial jobs in the digital age, Position Paper 2015-02. Document adopted by the 7th Meeting of the Executive Committee, Brussels, 02-03 December 2015, 
industriAll 66/2015. http://www.industriall-europe.eu/database/ uload/pdf/2015929PositionPaper_2015-XX_DigitalisationOfIndustry_DRAFTv1.pdf.

6. De Groen, W. P., Lenaerts K., Bosc R. and Paquier F. Impact of digitalisation and the on-demand economy on labour markets and the consequences for employment and industrial relations. European Economic and Social Committee. European Union, 2017. P.58 ISBN 978-92-830-3421-6 doi:10.2864/156665

7. Degryse, Christophe. 2016. Digitalisation of the Economy and its Impact on Labour Markets (February 10, 2016). // http://dx.doi.org/10.2139/ssrn.2730550.

8. Shestakova, I.G. (2018) To the question of the limits of progress: is singularity possible? Vestn. Saint Petersbg. Univ. Philos. Confl. Stud. 34 (2018). https://doi.org/10.21638/11701/spbu17.2018.307

9. World Development Report 2019 : The Changing Nature of Work : Main Report (English). Washington, D.C. : World Bank Group. http://documents.worldbank.org/curated/en/816281518818814423/Main-Report

10. Accelerating Workforce Reskilling for the Fourth Industrial Revolution URL: http://www3.weforum.org/docs/WEF_EGW_White_Paper_Reskilling.pdf.

11. UNESCO Global Network of Learning Cities. https://uil.unesco.org/lifelong-learning/learning-cities

12. Bylieva D., Zamorev A., Lobatyuk V., Anosova N. (2021) Ways of Enriching MOOCs for Higher Education: A Philosophy Course. In: Bylieva D., Nordmann A., Shipunova O., Volkova V. (eds) Knowledge in the Information Society. PCSF 2020, CSIS 2020. Lecture Notes in Networks and Systems, vol 184. Springer, Cham. https://doi.org/10.1007/978-3-030-65857-1_29

13. Shipunova, O. D., \& Berezovskaya, I. P. (2019). Organization technology of professional interactions in the engineering environments. International Journal of Civil Engineering and Technology, 9(10), 2020-2028.

14. Serkova, V. The Digital Reality: Artistic Choice. (2020). IOP Conference Series: Materials Science and Engineering, 2020, 940(1), 012154. doi:10.1088/1757-899X/940/1/012154.

15. NGA 2017 SUMMER MEETING - Introducing the New Chair's Initiative "Ahead of the Curve". https://www.youtube.com/watch?v=2C-A797y8dA\&ab_channel=NationalGovernorsAssociation;

16. The robot that takes your job should pay taxes, says Bill Gates https://qz.com/911968/bill-gates-the-robot-that-takes-your-job-should-pay-taxes/;

17. Jack Ma: In 30 years, the best CEO could be a robot. https://money.cnn.com/2017/04/24/technology/alibaba-jack-ma-30-years-pain-robot-ceo/index.html

18. World Economic Forum Annual Meeting. 2016. URL: https://www.weforum.org/events/world-economic-forum-annual-meeting-2016/programme.

19. Report of the 2018 Group of Governmental Experts on Lethal Autonomous Weapons Systems. URL: https://www.unog.ch/80256EDD006B8954/(httpAssets)/20092911F6495FA7C125830E003F9A5B/\$file/2018_GGE+LAWS_Final+R eport.pdf

20. The Association for the Advancement of Artificial Intelligence. URL: https://www.aaai.org/

21. Bostrom N. Superintelligence: Paths, Dangers, Strategies. Oxford: Oxford University Press, 2014. URL: https://img.4plebs.org/boards/tg/image/1447/41/1447419125484.pdf

22. Müller VC. Ethics of Artificial Intelligence and Robotics // https://plato.stanford.edu/entries/ethics-ai/;

23. Bostrom N., Yudkowsky El. The Ethics of Artificial Intelligence

24. Fleetwood J. Public Health, Ethics, and Autonomous Vehicles // Am. J. Public Health. 2017. Apr.; no. 107 (4). P. 532-537;

25. Dornehl L. Forget Asimov's Three Laws, the U. K. Issues Official Ethics Guidance on Robots. URL: http://www.digitaltrends.com/computing/bsi-robot-ethics-guidelines

26. Goodman M. Future Crimes. Anchor Books. New York, 2015. P. 366

27. Lutz M. Carl von Siemens, 1829-1906: Ein Leben zwischen Familie und Weltfirma. Munich: C. H. Beck, 2013. Pp. 413;

28. Adams $H$. The Education of Henry Adams. 
29. Ferry J.-M. Robotisation, utilité sociale, justice sociale. — "Esprit", Paris, Janvier 1985, p. 97

30. Wiener N. The Human Use of Human Beings. New York: Houghton, 1989.

31. Licklider Joseph C. R. 1960. Man-Computer Symbiosis In: Transactions on Human Factors in Electronics, volume HFE-1, pp. 4-11, March 1960.

32. Fourastié J. Le progrès technique et l'évolution économique / Institut d'Études Politiques de Paris. Paris: les cours de Droit, 1952;

33. Fourastié J. Machinisme et bienêtre. Paris: Ed. de Minuit, 1951;

34. Heidegger M. Poetry, Language, Thought / Transl. and introd. by A. Hofstadter. New York, 1971. Pp. 160-184;

35. Carlson J. Television Entertainment and Political Socialization // Vetmeer J. P. In "Media" Res: Readings in Mass Media and American Politics. New York: McGraw-Hill, Inc., 1995;

36. Postman N. Amusing Ourselves to Death: Public Discourse in the Age of Show Business. New York: Penguin, 1985.

37. Bell, Daniel. The Coming of Post-Industrial Society: A Venture in Social Forecasting. New York: Basic Books, 1973.

38. Toffler A. Previews and Premises. Toronto; New York; Sidney, 1983;

39. Naisbitt John. Megatrends: Ten New Directions. Transforming Our Lives. New York: Warner Books,. 1982, 290 pp.

40. Shestakova, I.G. (2021) Progressophobia in the New Temporality of the Digital World. Voprosy Filosofii, 2021, 2021(7), cтp. 61-71 URL:https://pq.iph.ras.ru/article/view/6464 (date of request: 07.09.2020),DOI: https://doi.org/10.21146/0042-8744-2021-7-61-71.

41. Porter M. E. Strategy and the Internet. URL: https://hbr.org/2001/03/strategy-and-the-internet.

42. Porter, M. E. Competitive Strategy: Techniques for Analyzing Industries and Competitors. New York: Free Press, 1980. P. $231-239$.

43. Will Robots Really Steal Our Jobs? An International Analysis of the Potential Long-Term Impact of Automation, February 2018. URL: https://www.pwc.co.uk/economic-services/assets/international-impact-of-automation-feb-2018.pdf;

44. Future of Work, Future of Society, December 2018. . URL: https://ec.europa.eu/info/sites/info/files/research_and_innovation/ege/ege_future-of-work_opinion_122018.pdf;

45. High-Level Expert Group on the Impact of the Digital Transformation on EU Labour Markets. URL: https://ec.europa.eu/digital-single-market/en/high-level-expert-group-impact-digital-transformation-eu-labour-markets.

46. Townsend A. Dying careers and thriving careers: the jobs of tomorrow. URL: https://edition.cnn.com/2012/08/13/opinion/careers-tomorrow-townsend/index.html.

47. Human body part designers and guided Space tours? Get ready for the jobs of the future. URL: https://news.microsoft.com/en-gb/2016/08/09/human-limb-designers-and-nine-other-jobs-we-will-need-in-the-future/.

48. McCarthy J. What is Artificial Intelligence? Stanford, CA: Stanford University, 2007. URL: http://www-formal.stanford.edu/jmc/whatisai.pdf.

49. Singer, Isaac Bashevis. The Golem. New York: FSG (1982).

50. Castells, M., 2010. The Information Age: Economy, Society and Culture Volume 1: The Rise of the Network Society. 2nd ed. Oxford: Wiley Blackwell;

51. Veblen, Thorstein (1994). The Theory of the Leisure Class: An Economic Study of Institutions. Penguin twentieth-century classics. New York: Penguin Books. 1994. P.51-62.

52. “Arizona Dream”, Emir Kusturica, 1993.

53. Keynes J. M. Economic Possibilities for our Grandchildren. P. 358-373.

54. Frankl V. Man's Search for Meaning. P. 235.

55. The Stanford Artificial Intelligence Laboratory (SAIL). https://ai.stanford.edu/;

56. Machine Intelligence Research Institute https://intelligence.org/ ;

57. Eindhoven Artificial Intelligence Systems Institute. https://www.tue.nl/en/research/institutes/eindhoven-artificial-intelligence-systems-institute/.

58. Barrat, James. Our Final Invention: Artificial Intelligence and the End of the Human Era. St Martin's Press (NY), 2013; 
59. Decree of the Government of the Russian Federation of August 19, 2020 No. 2129-r On approval of the Concept for the development of regulation of relations in the field of artificial intelligence technologies and robotics for the period up to 2024.

60. A well-known example is when the freed Luddite weavers later became in demand in the coal mines.

61. De Stefano, V. 2015. "The rise of the 'just-in-time workforce': On-demand work, crowd work and labour protection in the 'gig-economy"'. Comparative Labor law and Policy Journal 37(3): 471-503. http:// dx.doi.org/10.2139/ssrn.2682602;

62. Johnston, Hannah, Chris Land-Kazlauskas. 2019. Organizing on-demand: Representation, voice, and collec- tive bargaining in the gig economy. Geneva: ILO;

63. Valsamis et al. (2015) Employment and skills aspects of the digital single market strategy, European Parliament. http://www.europarl.europa.eu/RegData/etudes/STUD/2015/569967/IPOL_STU(2015)569967_EN.pdf.

64. Dosen, Igor, Michael Graham. 2018. Labour rights in the gig economy: An Explainer . Melbourne: Parliament of Victoria. https://www.parliament.vic.gov.au/publications/research-papers/download/36-research-papers/13869-labour-rights-in-the-gig-econom y-an-explainer.

65. The Future of Jobs Report 2020. http://www3.weforum.org/docs/WEF_Future_of_Jobs_2020.pdf

66. Vivarelli M. Innovation, employment and skills in advanced and developing countries: A survey of economic literature // Journal of Economic Issues. 2014. Vol. 48, No. 1. P. 123-154. 